\title{
Detection of Geminiviruses in Sweetpotato by Polymerase Chain Reaction
}

\author{
Ruhui Li, Sarbagh Salih, and Suzanne Hurtt, United States Department of Agriculture-Agricultural Research \\ Service, Fruit Laboratory/Plant Germplasm Quarantine Office, Beltsville, MD 20705
}

\begin{abstract}
Li, R., Salih, S., and Hurtt, S. 2004. Detection of geminiviruses in sweetpotato by polymerase chain reaction. Plant Dis. 88:1347-1351.

Geminivirus infection of sweetpotato (Ipomoea spp.) germplasm acquired from foreign regions is common. Graft inoculation of the indicator host, Ipomoea setosa, is the accepted detection method for these viruses, but the assay is laborious and requires up to 8 weeks. When infected sweetpotato is subjected to meristem tip culture to eliminate these viruses, the eradication rate is low. In this study, a polymerase chain reaction (PCR) detection assay was developed for the detection of geminiviruses in a variety of sweetpotato cultivars. Different methods were evaluated to extract nucleic acids suitable for PCR from Ipomoea spp., and a reliable and simple extraction method was developed for large-scale sample preparation. PCR products of the expected sizes were amplified from infected plants using degenerate and virus-specific primers, but not from noninoculated indicator plants. PCR assays using three primer pairs detected nine uncharacterized isolates of the geminiviruses in sweetpotato from Asia and America. However, the best PCR result was obtained with degenerate primers SPG1/SPG2, which detected a Taiwan isolate of Sweet potato leaf curl virus (SPLCV-Taiwan) in a sample diluted to $10^{-9}$. Viral identities of three amplicons from SPLCV-Taiwan were confirmed by sequencing. The degenerate primers had a broader detection range than virus-specific primers; therefore, they were used to detect geminiviruses in in vitro plantlets and greenhouse-grown sweetpotato plants, and in several Ipomoea hosts. PCR was shown to be as reliable for virus detection as grafting.
\end{abstract}

Additional keywords: begomoviruses, DNA extraction, Ipomoea leaf curl virus, Ipomoea yellow vein virus, malate dehydrogenase

Geminiviruses (family Geminiviridae) are plant viruses that have a circular, single-stranded DNA genome encapsidated within twinned isometric particles (8). They are grouped into four genera based on insect vector, host range, and genome organization (8). Members of the genus Begomovirus are transmitted by whiteflies, have single or bipartite component genomes, and infect dicotyledonous plants. Three geminiviruses, Sweet potato leaf curl virus (SPLCV, AF104036), Ipomoea crinkle leaf curl virus (ICLCV), and Ipomoea leaf curl virus (ILCV, AF326775) have been reported to infect sweetpotato (Ipomoea batatas) $(3,5,14)$, whereas Ipomoea yellow vein virus (IYVV, NC_003879), has been isolated from $I$. indica (1). Occurrence of geminiviruses in sweetpotato is widespread $(1,3-5,9,10,12-$ 16 ), and they commonly have been found in imported germplasm by virus indexing in quarantine (unpublished data). Geminiviruses are of particular significance to

Corresponding author: R. Li

E-mail: pgqorl@ars-grin.gov

Accepted for publication 2 July 2004.

Publication no. D-2004-0913-02R

This article is in the public domain and not copyrightable. It may be freely reprinted with customary crediting of the source. The American Phytopathological Society, 2004. quarantine programs because infected plants are essentially symptomless $(4,14)$, and recombination or reassortment among species and strains could lead to occurrence of more virulent strains or species (19). To detect these viruses, vine segments from sweetpotato are graft inoculated onto an indicator host, I. setosa, which develops symptoms if the source material was infected $(5,12,14,15)$. To ensure accuracy, the grafting assay has to be done twice. Infected materials undergo meristem tip culture with or without therapeutic treatments for virus elimination, but the rate of eradication is low. To identify a virus-free clone, many in vitro plantlets have to be grown in the greenhouse, and then tested two times by the grafting assay.

Nucleic acid-based techniques, including polymerase chain reaction (PCR), offer the potential of great savings in time, greenhouse space, efficiency, and cost. The genomic sequences of three geminiviruses that infect Ipomoea spp., and those for many other geminiviruses, are available and can be utilized for designing primers for detection of geminiviruses in sweetpotato by PCR. In this article, the use of PCR to detect SPLCV and several other geminiviruses of sweetpotato is reported. The PCR assay developed was used to test in vitro plantlets generated from infected sweetpotato, greenhouse-grown sweetpotato plants, and grafted indicator plants, and the sensitivity of the PCR was compared with that of the grafting assay.

\section{MATERIALS AND METHODS}

Virus isolates. Twenty sweetpotato accessions naturally infected with viruses from Brazil, China, Guatemala, Guyana, Jamaica, Korea, Mexico, Puerto Rico, Taiwan, and Vietnam were maintained in the Plant Germplasm Quarantine Office (PGQO) quarantine facilities. Most accessions were cultivars, and several accessions from Taiwan were hybrids from crosses of I. batatas and I. trifida. These accessions were infected by either geminivirus or geminivirus and other virus of sweetpotato based on development of symptoms when grafted onto I. setosa and on immunoblotting assays using antisera against several sweetpotato viruses. These isolates were maintained in greenhousegrown plants and in in vitro plantlets propagated from the infected sweetpotato accessions. Noninoculated indicator plants and sweetpotato accessions with negative results from grafting and immunoblotting assays were used as negative controls.

DNA extracts of Bean golden mosaic virus (BGMV), Cabbage leaf curl virusFlorida $(\mathrm{CaLCuV})$, Tomato yellow leaf curl virus (TYLCV), and Tomato mottle virus (ToMoV) were kindly provided by $\mathrm{E}$. Hiebert (University of Florida). DNA extracts of Beet curly top virus (BCTV), Cotton leaf crumple virus (CLCrV), and Squash leaf curl virus (SLCV) were kindly provided by H.-Y. Liu (United States Department of Agriculture-Agricultural Research Service, Salinas, CA) and ILCV was kindly provided by R. A. Valverde (Louisiana State University).

In vitro plantlets. Shoots $5 \mathrm{~cm}$ in length were taken from infected accessions and micropropagated in vitro on Murashige and Skoog (MS) basal salts (17) supplemented with MS vitamins, thiamine at $0.3 \mathrm{mg} / \mathrm{liter}$, sucrose at $30 \mathrm{mg} / \mathrm{liter}$, and gelrite (Sigma-Aldrich, St. Louis) at 1.5 g/liter. Plant growth regulators were not needed for micropropagation or rooting. Most accessions grew vigorously and induced roots easily in the same medium. Plantlets were maintained at ambient temperature with $16 \mathrm{~h}$ of cool white fluorescent light $\left(40 \mu \mathrm{mol} \mathrm{m} \mathrm{m}^{2} \mathrm{~s}^{-1}\right)$ per day. Meristem tip cultures were prepared from infected shoots directly or after different therapeutic treatments. Sixty-two in vitro plantlets generated from seven infected sweetpotato accessions then were tested by PCR at lease twice for presence of gemi- 
nivirus, and virus-free clones were selected.

DNA extraction. Shoots or leaves $(100$ $\mathrm{mg}$ ) were collected from in vitro plantlets, greenhouse-grown sweetpotato plants, and grafted I. setosa plants. In the initial tests, nucleic acids were extracted from plant tissues using plant DNAzol buffer (Invitrogen, Carlsbad, CA) according to the method described by Lotrakul et al. (12). Fresh shoot and leaf tissue was ground to fine powder in liquid nitrogen with a mortar and pestle and either used for nucleic acid extraction or stored at $-30^{\circ} \mathrm{C}$ for future use. Other frozen, powdered leaf tissues, stored at $-30^{\circ} \mathrm{C}$ for about 1 year, also were used. To simplify the extraction method and avoid contamination between samples, a semi-automatic homogenizer, FastPrep Instrument (Savant Instruments Inc., Holbrook, NY), which holds 2-ml microtubes containing plant tissues, extraction buffer, and two steel beads, was used for nucleic acid extraction.

Two nucleic acid extraction protocols, one using plant DNAzol buffer and another using cetyltrimethylammonium bromide (CTAB) buffer (2\% CTAB, 2\% polyvinylpyrrolidone [PVP], $100 \mathrm{mM}$ Tris$\mathrm{HCl}, \mathrm{pH}$ 8.0, $1.4 \mathrm{M} \mathrm{NaCl}, 20 \mathrm{mM}$ EDTA, and $0.2 \%$ 2-mecaptoethanol) (7), were tested in the FastPrep Instrument. The method using CTAB then was selected for large-scale processing of samples. Plant tissues $(100 \mathrm{mg})$ cooled in a $-30^{\circ} \mathrm{C}$ freezer were processed in $1 \mathrm{ml}$ of CTAB at a speed set of 4.5 for $60 \mathrm{~s}$ in the FastPrep Instrument. The homogenate was incubated at $65^{\circ} \mathrm{C}$ for $15 \mathrm{~min}$ and centrifuged at 10,000 $\times g$ for $10 \mathrm{~min}$. The supernatant $(650 \mu \mathrm{l})$ was transferred to a $1.5-\mathrm{ml}$ microcentrifuge tube and mixed with an equal volume of chloroform:isoamyl alcohol (24:1). The mixture was centrifuged at $12,000 \times \mathrm{g}$ for $10 \mathrm{~min}$ and the supernatant $(500 \mu \mathrm{l})$ was transferred to a $1.5-\mathrm{ml}$ microcentrifuge tube before adding $350 \mu \mathrm{l}$ of isopropanol. The mixture was incubated on ice for $10 \mathrm{~min}$ and centrifuged at $12,000 \times g$ for $10 \mathrm{~min}$. The pellet was washed with $70 \%$ ethanol and centrifuged at $12,000 \times g$ for $5 \mathrm{~min}$. The pellet was air dried and dissolved in $100 \mu \mathrm{l}$ of $20 \mathrm{mM}$ Tris-HCl, pH 8.0.

Oligonucleotide primers. In initial PCR tests, the SPLCV-specific primers
PW285-1/PW285-2 (14) were used. Inconsistent results were obtained when the same plantlets were assayed by PCR two times in 2 months. To increase PCR sensitivity and detection range, two additional pairs of primers, degenerate primers SPG1/SPG2 and specific primers SPG3/SPG4, were designed and tested in PCR assays (Table 1). To design degenerate primers, the genomic sequences of the following 11 Begomovirus were obtained from GenBank (National Center for Biotechnology Information): SPLCV-US (AF104036), ILCV (AF326775), IYVV (NC_003879), Chili leaf curl virus (AF314531), Papaya leaf curl virus (NC_004147), Cotton leaf curl virus (CLCVAJ455), SLCV (SLE420319), Ageratum yellow vein virus (AF327902), Tobacco leaf curl virus (TLE319674), Soybean crinkle leaf virus (AB050781), and Tomato leaf curl virus (AF327436). The sequences of each genome were aligned directly using CLUSTALW (EMBL-EBI, UK). Based on alignments, degenerate primers SPG1/SPG2 were designed to bind to conserved regions in open reading frame (ORF) AC2 and ORF $\mathrm{AC} 1$ of these viruses. Specific primers SPG3/SPG4 were designed to anneal to the nucleotide sequences in the coat protein gene (AV1) and ORF AC2 of SPLCV and ILCV. Primers MDH-H968 and MDHC1163, designed for detection of the malate dehydrogenase (MDH) gene of host plants (18), were used to check the quality of the nucleic acids extracted in PCR assays.

PCR. The volume of the DNA extract, primer concentration, and PCR temperature conditions were optimized on a $\mathrm{Hy}$ baid PCR Express thermocycler (Thermo Hybaid US, Franklin, MA). The optimized amplification was performed in $30-\mu \mathrm{l}$ reaction volumes containing $1 \mu \mathrm{l}$ of the DNA extract, $0.6 \mu \mathrm{l}$ of each primer $(10 \mu \mathrm{M}), 0.6$ $\mu \mathrm{l}$ of $10 \mathrm{mM}$ dNTP mix, $3 \mu \mathrm{l}$ of 10x Taq DNA polymerase reaction buffer, $2 \mu \mathrm{l}$ of $50 \mathrm{mM} \mathrm{MgCl} 2,0.2 \mu \mathrm{l}(1 \mathrm{U})$ of Taq DNA polymerase (Invitrogen, Carlsbad, CA), and $22 \mu \mathrm{l}$ of water. Touchdown PCR conditions used were as follows: 11 cycles of $94^{\circ} \mathrm{C}$ for $40 \mathrm{~s},(72-\mathrm{n})^{\circ} \mathrm{C}$ for $40 \mathrm{~s}$ (n equals cycle number), $72^{\circ} \mathrm{C}$ for $90 \mathrm{~s} ; 24$ cycles of $94^{\circ} \mathrm{C}$ for $40 \mathrm{~s}, 60^{\circ} \mathrm{C}$ for $40 \mathrm{~s}, 72^{\circ} \mathrm{C}$ for 90 $\mathrm{s}$; and $72^{\circ} \mathrm{C}$ for $10 \mathrm{~min}$. PCR products were assessed by electrophoresis in 1 or $1.2 \%$ agarose gels in Tris-acetate (TAE) buffer ( $40 \mathrm{mM}$ Tris-acetate, $1 \mathrm{mM}$ EDTA, $\mathrm{pH}$ 8.0), stained with ethidium bromide, and viewed under ultraviolet light.

Cloning and sequencing. The PCR products $(1,148,912$, and $514 \mathrm{bp})$ amplified from extracted DNA of SPLCV-Taiwan were purified using the QIAquick PCR Purification Kit (QIAGEN Inc., Valencia, CA) according to the manufacturer's instructions. Eluted DNA was cloned into pGEM-T Easy vector (Promega Corp., Madison, WI) according to the manufacturer's instructions. The nucleotide sequence was determined for both directions of the clones using an automated DNA sequencer (Auburn Genomics and Sequencing Lab, Auburn University, AL). Sequences were compared with those available for SPLCV, ILCV, or IYVV using Sequence Analysis (Southampton Bioinformatics Data Server, University of Southampton, UK).

Comparison of PCR and grafting assays. To determine the reliability of the PCR, 16 plantlets derived from two infected accessions were assayed by grafting onto I. setosa at the PGQO greenhouse. These plantlets were tested three times by PCR within 2 months before grafting assay, and both positive and negative plantlets from each accession were included. Plantlets were planted in soil pots and maintained in the greenhouse after a 14 day acclimation period in a growth chamber. Approximately 6 weeks later, two to three vine segments (two to four nodes) were taken from each plant and wedge grafted onto 4- to 7-week-old indicator plants, which were observed periodically for symptom development for 8 weeks. The grafted plants typically showed symptoms 3 to 4 weeks after inoculation if the source material was infected.

\section{RESULTS}

Sample preparation. In initial experiments, PCR for DNA samples extracted by grinding plant tissues in liquid nitrogen with mortars and pestles in plant DNAzol buffer always resulted in the expected fragments (Figs. 1A, 2, and 3). PCR assays failed to detect the viruses in the nucleic

Table 1. Primer pairs used for the detection of geminiviruses in sweetpotato and respective amplicon produced by polymerase chain reaction (PCR)

\begin{tabular}{|c|c|c|c|c|}
\hline Name & Orientation & Sequence & Location $^{a}$ & Product size (bp) \\
\hline PW285-1 ${ }^{\mathrm{b}}$ & Sense & 5'-TAATTCGAACTGCAGTTCCGTATTTCAGTT-3' & $1795-1828$ & 514 \\
\hline PW285-2 & Antisense & 5'-GCTAGAGGAGGCCTGCAGACTGCTAACGACG-3' & $2308-2278$ & \\
\hline SPG1 & Sense & 5'-CCCCKGTGCGWRAATCCAT-3' & $1490-1508$ & 912 \\
\hline SPG2 & Antisense & 5'-ATCCVAAYWTYCAGGGAGCTAA-3' & $2412-2391$ & \\
\hline SPG3 & Sense & $5^{\prime}$-ACTTCGAGACAGCTATCGTGCC-3' & $363-385$ & 1,148 \\
\hline SPG4 & Antisense & 5'-AGCATGGATTCACGCACAGG-3' & $1511-1492$ & $\ldots$ \\
\hline MDH-H968 & Sense & 5'-GCATCTGTGGTTCTTGCAGG-3' & $\ldots$ & 196 \\
\hline $\mathrm{MDH}-\mathrm{C} 1163^{\mathrm{c}}$ & Antisense & 5'-CCTTTGAGTCCACAAGCCAA-3' & $\ldots$ & $\ldots$ \\
\hline
\end{tabular}

\footnotetext{
${ }^{a}$ Numbers indicate the locations of different primers on the sequence of the U.S. isolate of Sweet potato leaf curl virus (12).

b Primers used by Lotrakul et al. (1998).

${ }^{\mathrm{c}}$ Internal primers that anneal to the sequences of the malate dehydrogenase gene of the host plants (18).
} 
acids extracted using the FastPrep Instrument if microcentrifuge tubes containing plant tissues in DNAzol buffer were not cooled in a $-30^{\circ} \mathrm{C}$ freezer before processing (data not shown). Virus was detected in only 4 of 14 positive samples in a set of 42 plantlets when plant tissues in DNAzol buffer were cooled before processing in the FastPrep Instrument. However, when CTAB was used instead of DNAzol buffer, DNA extracts obtained from cooled plant tissues using the FastPrep Instrument gave the same results in the PCR assay as those obtained by grinding tissue in liquid nitrogen (Fig. 1; data not shown), indicating that this extraction method was reliable.

Host primers MDH-H968 and MDHC1163 were used to confirm that the DNA extracts were suitable for PCR. PCR amplification with these primers yielded a 400-bp DNA fragment from extracts of several Ipomoea spp. Two expected products, one of virus origin (912 bp) and the other of host origin (400 bp), were coamplified by PCR when both viral and MDH primers were used with infected samples (Fig. 1). False negative results were identified by the absence of the 400bp amplicon (Fig 1A, lanes 16 and 18).

Sensitivity of primer pairs. Initial PCR assays using primers PW285-1/PW285-2, developed by Lotrakul and Valverde (14), for SPLCV-Taiwan yielded a major amplicon of 514 bp (Fig. 2A). No PCR amplicons were produced using the DNA extracts of noninoculated plants. However, these primers gave inconsistent results when the same in vitro plantlets were tested two times within 2 months (data not shown). To increase the sensitivity and detection range, degenerate primers SPG1/SPG2 and specific primers SPG3/SPG4 were compared with primers PW285-1/PW285-2 in PCR assays and found to be highly sensitive (Fig. 2B and C). Three PCR assays were carried out on 10-fold dilutions of DNA extracted from a plantlet infected with SPLCV-Taiwan. PCR results indicated an endpoint at $10^{-3}$ (an equivalent of $2 \mu \mathrm{g}$ of plant tissues) for primers PW285-1/PW285-2, at least $10^{-9}$ (2 pg) for degenerate primers SPG1/SPG2 (no endpoint was obtained), and at $10^{-5}$ (20 ng) for primers SPG3/SPG4 (Fig. 2). The PCR results for DNA extracted from the plant infected with SPLCV-Taiwan indicated a single amplicon of 912 bp for degenerate primers SPG1/SPG2, and a major amplicon of 1,148 bp for primers SPG3/SPG4.

The nucleotide sequences for the three PCR clones obtained from the Taiwan isolate shared 86.2 to $96.9 \%$ identity with SPLCV-US, confirming that it is an isolate of SPLCV and that the amplicons were of viral origin, as expected.

Specificity of primer pairs. To determine the range of detection, nine isolates of geminiviruses infecting sweetpotato from five different geographic regions

\section{$\begin{array}{lllllllllllllllllll}1 & 2 & 3 & 4 & 5 & 6 & 7 & 8 & 9 & 10 & 11 & 12 & 13 & 14 & 15 & 16 & 17 & 18 & 19\end{array}$}

A

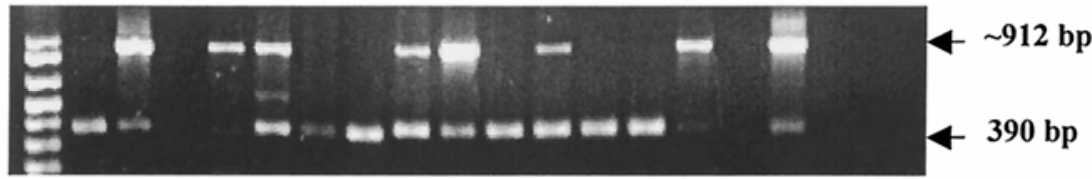

B

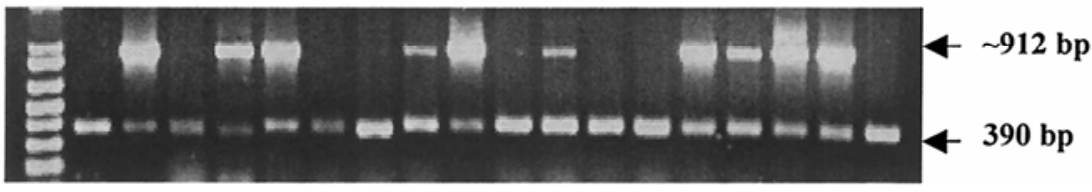

Fig. 1. Comparison of two DNA extraction methods by the polymerase chain reaction for detection of the geminiviruses in indicator host, Ipomoea setosa, and greenhouse-grown sweetpotato plants. The DNA extracts were obtained by either $\mathbf{A}$, grinding plant tissue in liquid nitrogen with mortar and pestle and then mixing with plant DNAzol buffer or $\mathbf{B}$, grinding plant tissue cooled at $-30^{\circ} \mathrm{C}$ in cetyltrimethylammonium bromide buffer with FastPrep Instrument. The degenerate primers SPG1/SPG2 amplified a 912-bp product from the infected plants, and the internal primers $\mathrm{MDH}-\mathrm{H} 968 / \mathrm{MDH}$ C1063 amplified a 400-bp fragment from host plants. Lane 1, 1-kb DNA ladder; lanes 2-11, the graftinoculated indicator plants; and lanes $12-18$, greenhouse-grown sweetpotato plants.

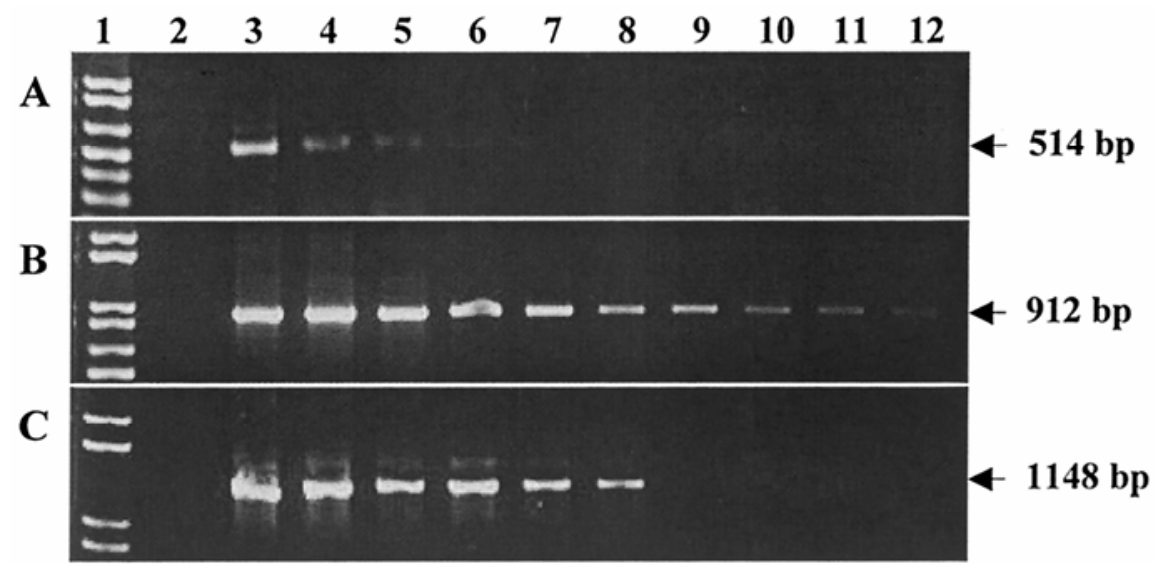

Fig. 2. Polymerase chain reaction (PCR) products amplified from dilutions of the DNA extracted from a plantlet infected with a Taiwan isolate of Sweet potato leaf curl virus. Lane 1, 1-kb DNA ladder; lane 2, healthy plantlet; lane 3, undiluted DNA extract from infected plantlet; lanes 4-12, 10-fold serial dilutions: lane $4,10^{-1}\left(200 \mu \mathrm{g}\right.$ of plant tissue); lane $5,10^{-2}(20 \mu \mathrm{g})$; lane $6,10^{-3}(2 \mu \mathrm{g})$; lane $7,10^{-4}$ (200 ng); lane 8, $10^{-5}(20 \mathrm{ng})$; lane $9,10^{-6}(2 \mathrm{ng})$; lane $10,10^{-7}(200 \mathrm{pg})$; lane $11,10^{-8}(20 \mathrm{pg})$; and lane $12,10^{-9}(2 \mathrm{pg})$. Primers were A, PW285-1/PW285-2, B, SPG1/SPG2, C, and SPG3/SPG4. Arrows indicate the positions of the $\mathbf{A}, 514-b p, \mathbf{B}, 912-b p$, and $\mathbf{C}, 1,148-b p$ PCR amplicons.

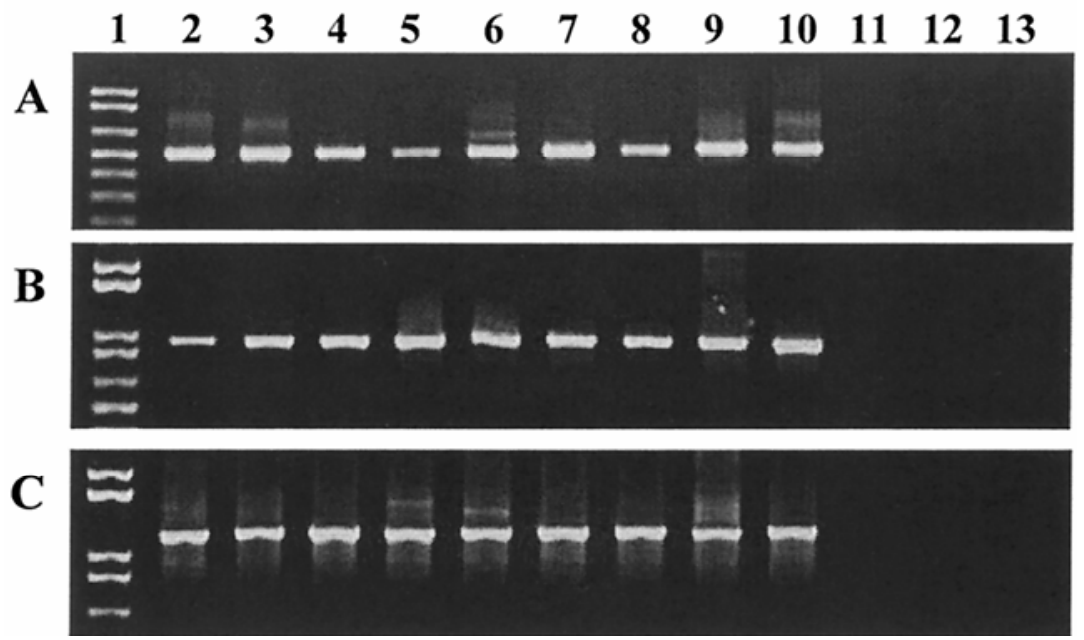

Fig. 3. Detection of sweetpotato geminivirus isolates by polymerase chain reaction (PCR) using primers A, PW285-1/PW285-2, B, SPG1/SPG2, or C, SPG3/SPG4. Lane 1, 1-kb DNA ladder; lanes 2 and 3, two isolates from China; lane 4, Korean isolate; lanes 5 and 6, two isolates from Taiwan; lane 7, Brazilian isolate; lane 8, Mexican isolate; lanes 9 and 10, two isolates from Puerto Rico; lane 11, uninoculated Ipomoea setosa; and lanes 12 and 13, potyviruses used as negative controls. Amplicon sizes are A, 514 bp, B, 912 bp, and C, 1,148 bp. Five times more PCR product was loaded for gel A than for gels $\mathrm{B}$ and $\mathrm{C}$. 
were examined by PCR using three primer pairs, PW285-1/PW285-2, SPG1/SPG2, and SPG3/SPG4 (Fig. 3). There was no discernible difference in the sizes of the amplicons obtained from all nine isolates, although nonspecific bands were observed when primers PW285-1/PW285-2 or SPG3/SPG4 were used.

To determine if these three pairs of primers could amplify similar-sized products from other geminiviruses, we tested DNA extracts of two uncharacterized sweetpotato geminivirus isolates, ILCV and seven geminiviruses infecting different hosts by PCR (Fig. 4). PCR assays using primers PW285-1/PW285-2, SPG1/SPG2, and SPG3/SPG4 yielded amplicons of the same size $(514,912$, and $1,148 \mathrm{bp})$ for two uncharacterized sweetpotato geminivirus isolates and ILCV. Very weak or no amplicons were produced for DNA extracts of other non-sweetpotato geminiviruses by the primers PW285-1/PW285-2 and
SPG3/SPG4 in PCR (Fig. 4A and C). However, DNA fragments of different sizes were amplified from seven nonsweetpotato geminiviruses by PCR using the degenerate primers SPG1/SPG2. All PCR amplicons except that of BCTV were smaller than those for sweetpotato geminiviruses (Fig. 4B). When in vitro plantlets were tested by PCR, geminiviruses were detected in 40 of the 62 plantlets using primers SPG1/SPG2, compared with 29 using primers PW285-1/PW285-2 (data not shown). Consequently, the SPG1/SPG2 primers, together with the MDH primers, were selected as the best primers for PCRbased detection of the geminiviruses in sweetpotato.

Comparison of PCR and grafting. During the summer, I. setosa plants infected with geminiviruses developed leaf curl symptoms approximately 3 weeks after grafting. Under greenhouse conditions during the fall, symptoms consisted

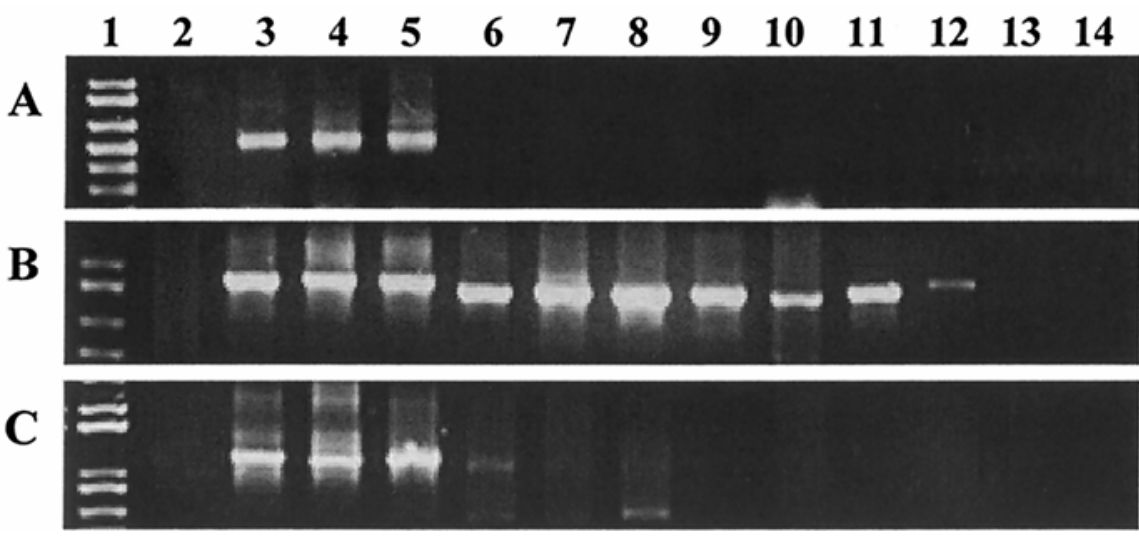

Fig. 4. Detection of different geminiviruses by polymerase chain reaction (PCR) using primers A, PW285-1/PW285-2, B, SPG1/SPG2, or C, SPG3/SPG4. Lane 1, 1-kb DNA ladder; lane 2, uninoculated Ipomoea setosa; lane 3, an uncharacterized Jamaican isolate infecting sweetpotato; lane 4, an uncharacterized Puerto Rican isolate infecting sweetpotato; lane 5, Ipomoea leaf curl virus; lane 6, Tomato yellow leaf curl virus; lane 7, Tomato mottle virus; lane 8, Bean golden mosaic virus; lane 9, Cabbage leaf curl virus; lane 10, Squash leaf curl virus; lane 11, Cotton leaf crumple virus; lane 12, Beet curl top virus; lane 13, a potyvirus infecting sweetpotato used as negative control, and lane 14, water control. Five times more PCR product was loaded for gel A than for gels B and C.

Table 2. Comparisons of the polymerase chain reaction (PCR) assays and grafting for detection of geminiviruses in sweetpotato plantlets

\begin{tabular}{lccc}
\hline Plantlet no. & First PCR $^{\mathbf{a}}$ & Second PCR $^{\mathbf{b}}$ & Symptoms in $^{\text {Ipomoea setosa }} \mathbf{c}$ \\
\hline 1 & + & + & + \\
2 & + & + & + \\
3 & + & + & + \\
4 & + & + & + \\
5 & - & + & + \\
6 & - & + & + \\
7 & - & - & + \\
8 & - & + & - \\
9 & + & + & + \\
10 & + & + & + \\
11 & + & + & + \\
12 & + & - & + \\
13 & + & + & + \\
14 & - & - & - \\
15 & + & + & - \\
16 & - & + & + \\
\hline
\end{tabular}

a Primer pair PW285-1/PW285-2 was used in the PCR.

${ }^{\mathrm{b}}$ Primer pair SPG2/SPG2 was used in the PCR.

${ }^{\mathrm{c}}$ Tested plantlets were grown in a greenhouse and graft inoculated to indicator host $I$. setosa.

of bleaching of the internal leaf tissue, with or without upward curling of the leaf margins. The results of the grafting assay for 16 plantlets correlated very well with those of the PCR assay using primers SPG1/SPG2 (Table 2). Several in vitro clones that were negative by PCR and grafting assays were propagated and released as virus-free materials to customers.

\section{DISCUSSION}

Previously, the only reliable test for detection of geminiviruses in sweetpotato germplasm in a quarantine indexing program was a grafting assay. Hybridization assays using probes generated from clones of other geminiviruses (i.e., BGMV) have been used to detect ICLCV and SPLCVUS in sweetpotato $(5,14)$. PCR using both degenerate and virus-specific primers also has been used for virus detection and identification in indicator plants $(1,14)$. Despite the use of the above techniques for virus detection in experimentally infected plants, they have not been used in the virusindexing program due to the lack of a comparative evaluation with the grafting assay, the standard detection method.

In this study, the successful application of PCR to detect 20 different geminivirus species or isolates in both in vitro plantlets and greenhouse-grown sweetpotato plants, and in Ipomoea spp. indicator plants, was reported. The extraction method using plant DNAzol buffer and liquid nitrogen yielded suitable quality DNA for PCR, but it was laborious and time consuming. Several DNA extraction kits designed for isolation of DNA from plant samples are now available. However, the kits are too expensive for use in the virus-indexing program because many samples have to be tested. The DNA extraction method described by Doyle and Doyle (7) was modified and used for sample preparation in the FastPrep Instrument. This method uses a common buffer, CTAB, and a semiautomatic homogenizer for sample preparation, and it allows for fast sample processing and minimizes cross contamination. The method has been used successfully to extract nucleic acids suitable for PCR not only from in vitro plantlets and three Ipomoea indicator hosts, but also from greenhouse-grown sweetpotato plants. The protocol is easily scalable to large numbers of samples in a virus-indexing or certification program. Both fresh and frozen tissue (at $-30^{\circ} \mathrm{C}$ for 1 year) could be used in DNA extractions without any significant differences in the quality of the extracts. DNA extracts stored at $-20^{\circ} \mathrm{C}$ for at least 1 year resulted in no loss of amplification.

Three pairs of primers were evaluated for use in detection of geminiviruses in sweetpotato by PCR assays. All primers amplified PCR products of predicted sizes from all geminivirus species and isolates infecting sweetpotato, regardless of geographic origin of the plant material. Thus, 
variation at the primer regions among these isolates is low. Interestingly, degenerate primers SPG1/SPG2 were more sensitive than the other primer pairs tested in the PCR assays. Degenerate primers have been used extensively in identification and detection of geminiviruses $(2,6,13,20,21)$. Sequence analyses revealed that the identity of the coat protein (CP) sequences between three geminiviruses infecting sweetpotato and other begomoviruses was less than $49 \%$, lower than those among other begomoviruses $(11,13)$. Therefore, degenerate primers based on the $\mathrm{CP}$ sequence for other non-sweet-potatoinfecting geminiviruses may not be suitable for detection of target viruses. Degenerate primers SPG1/SPG2 anneal to regions of ORFs $\mathrm{AC} 2$ and $\mathrm{AC} 1$ which are highly conserved in geminiviruses infecting sweetpotato and other begomoviruses. They amplified PCR products not only from geminiviruses infecting sweetpotato, but also from other geminiviruses tested. The high sensitivity and broad detection range of these primers make them the best choice for general use in PCR-based detection. The broad detection range of the degenerate primers also may aid in the detection of other uncharacterized geminiviruses in sweetpotato. The lack of effectiveness of primers PW285-1/ PW285-2 can be explained by three mismatches and one deletion in PW285-1 and by a single mismatch in PW285-2 when compared with the SPLCV-US sequence. The decreased sensitivity of primers SPG3/SPG4 probably is an artifact of PCR in which the longer PCR fragment cannot be replicated as efficiently as the shorter ones.

The use of primers MDH-H968 and MDH-C1163 in the PCR allowed for the simultaneous detection of host DNA and target viruses under the same PCR conditions. The MDH primers amplified a 400bp fragment, which is different from that obtained with the SPG primers for extracts of several Ipomoea spp., including $I$. aquatica, I. batatas, I. nil, and I. setosa. However, intensity of the host-specific band observed in the agarose gels decreased with increased storage period of the DNA extracts in the $-20^{\circ} \mathrm{C}$ freezer, but intensity of the geminivirus-specific bands did not decrease.

This PCR assay offers several advantages over the grafting assay in the sweetpotato indexing program. Sequence information determined from PCR products will be used for identifying uncharacterized geminiviruses in sweetpotato, examining genetic variations, and establishing taxonomic relationships. Rapid screening of in vitro plantlets generated from therapy eliminates the need to grow large numbers of plants in the greenhouse for grafting assay. Unlike the grafting assay, PCR can be carried out year-round, thereby speeding up dissemination of healthy plant material to the intended users and greatly reducing costs associated with elimination of geminiviruses from germplasm. Finally, the DNA extraction method and the PCR assay developed in this study also may be applicable to detection of geminiviruses in other crops that must be tested by PGQO or other similar institutions.

\section{ACKNOWLEDGMENTS}

We thank A. Murphy and C. Losckinkohl for technical assistance; W. Moskal for recommendation of the MDH primers in the virus detection system; and H.-Y. Liu, H.-T. Hsu, and J. Foster for review and helpful comments.

\section{LITERATURE CITED}

1. Banks, G. K., and Bedford, I. D. 1999. A novel geminivirus of Ipomoea indica (Convolvulacae) from southern Spain. Plant Dis. 83:486.

2. Briddon, R. W., and Markham, P. G. 1994. Universal primers for the PCR amplification of dicot-infecting geminiviruses. Mol. Biotechnol. 1:202-205.

3. Chung, M. L., Liao, C. H., Chen, M. J., and Chiu, R. J. 1985. The isolation, transmission, and host range of sweet potato leaf curl agent in Taiwan. Plant Prot. Bull. (Taiwan, ROC) 27:333-341.

4. Clark, C. A., and Moyer, J. W. 1988. Compendium of Sweet Potato Diseases. The American Phytopathological Society, St. Paul, MN.

5. Cohen, J., Milgram, M., Antignus, Y., Pearlsman, M., Lachman, O., and Loebenstein, G. 1997. Ipomoea crinkle leaf curl caused by a whitefly-transmitted gemini-like virus. Ann. Appl. Biol. 131:272-282.

6. Deng, D., McGrath, P. F., Robinson, D. J., and Harrison, B. D. 1994. Detection and differentiation of whitefly-transmitted geminiviruses in plants and vector insects by the polymerase chain-reaction with degenerate primers. Ann. Appl. Biol. 125(2):327-336.
7. Doyle, J. J., and Doyle, J. L. 1987. A rapid DNA isolation procedure for small quantities of fresh leaf tissue. Phytochem. Bull. 19:11-19.

8. Fauquet, C. M., Bisaro, D. M., Briddon, R. W. Brown, J. K., Harrison, B. D., Rybicki, E. P., Stenger, D. C., and Stanley, J. 2003. Revision of taxonomic criteria for species demarcation in the family Geminiviridae, and an updated list of begomovirus species. Arch. Virol. 148:405-421.

9. Girardeau, J. H., and Ratcliffe, T. J. 1960. The vector-virus relationship of the sweetpotato whitefly and a mosaic of sweetpotatoes in South Georgia. Plant Dis. Rep. 44:48-50.

10. Hildebrand, E. M. 1959. A whitefly, Trileurodes abutilonea, an insect vector of sweetpotato feathery mottle in Maryland. Plant Dis. Rep. 43:712-714.

11. Howarth, A. J., and Vandemark, G. J. 1989 Phylogeny of geminiviruses. J. Gen. Virol. 70:2717-2727.

12. Lotrakul, P., and Valverde, R. A. 1999. Cloning of a DNA-A like genomic component of sweet potato leaf curl virus: nucleotide sequence and phylogenetic relationships. Mol. Plant. Pathol. On-line.

13. Lotrakul, P., Valverde, R. A., Clark, C. A., Hurtt, S. S., and Hoy, M. W. 2002. Sweetpotato leaf curl virus and related geminiviruses in sweetpotato. Acta Hortic. 583:135-141.

14. Lotrakul, P., Valverde, R. A., Clark, C. A., Sim, J., and De La Torre, R. 1998. Detection of a geminivirus infecting sweet potato in the United States. Plant Dis. 82:1253-1257.

15. Moyer, J. M., Jackson, G. V. H., and Frison, E. A., eds. 1989. FAO/IBPGR Technical Guidelines for the Safe Movement of Sweet Potato Germplasm. Food and Agriculture Organization of the United Nations, Rome/International Board for Plant Genetic Resources, Rome.

16. Moyer, J. W., and Salazar, L. F. 1989. Viruses and viruslike diseases of sweet potato. Plant Dis. 73:451-455.

17. Murashige, T., and Skoog, F. 1962. A revised medium for rapid growth and bioassays with tobacco tissue cultures. Physiol. Plant. 15:473-497.

18. Nassuth, A., Pollari, E., Helmeczy, K., Stewart, S., and Kofalvi, S. A. 2000. Improved RNA extraction and one-tube RT-PCR assay for simultaneous detection of control plant RNA plus several viruses in plant extracts. J. Virol. Methods 90:37-49.

19. Padidam, M., Sawyer, S., and Fauquet, C. M. 1999. Possible emergence of new geminiviruses by frequent recombination. Virology 265(2):218-225.

20. Rojas, M. A., Gilbertson, R. L., Russell, D. R., and Maxwell, D. P. 1993. Use of degenerate primers in the polymerase chain reaction to detect whitefly-transmitted geminiviruses. Plant Dis. 77:340-347.

21. Wyatt, S. D., and Brown, J. K. 1996. Detection of subgroup III geminivirus isolates in leaf extracts by degenerate primers and polymerase chain reaction. Phytopathology 86:1288-1293. 